\title{
The Mediating Role of Attitude towards Distance Education in the Effect of Digital Literacy Level on Satisfaction with Distance Education
}

\section{Dijital Okuryazarlık Düzeyinin Uzaktan Eğitimden Memnuniyete Etkisinde Uzaktan Eğitime Yönelik Tutumun Aracı Rolü}

\section{Sami SEVER, Kahraman ÇATI}

\begin{abstract}
This study aims to examine whether the attitudes towards distance education have a mediating role in the effect of academicians' digital literacy levels on their satisfaction with distance education during the COVID-19 pandemic. The data were collected from 341 academicians who teach distance education courses at Inonu University. The academicians' satisfaction with distance education which is the dependent variable of the study, consisted of two factors. These factors are satisfaction with the teaching of the course and satisfaction with the infrastructure. As a result of the analysis, it was determined that the attitude towards distance education has a complete mediation role in the effect of digital literacy level on satisfaction with the teaching of the course in distance education, and that the attitude towards distance education has a partial mediation role in the effect of digital literacy level on satisfaction with the infrastructure.
\end{abstract}

Keywords: Covid-19, Digital Literacy, Distance Education, Satisfaction, Attitude

\section{öz}

Bu çalışmanın amacı, COVID-19 pandemi sürecinde akademisyenlerin dijital okuryazarlık düzeylerinin, uzaktan eğitim memnuniyetleri üzerindeki etkisinde uzaktan eğitime yönelik tutumlarının aracı rolünün olup olmadığını incelemektir. Araştırmanın amacına uygun olarak hazırlanan anket araclığı ile İnönü Üniversitesi’nde uzaktan eğitim veren 341 akademisyenden veriler toplanmıştır. Araştırmanın bağımlı değişkeni olan akademisyenlerin uzaktan eğitimden memnuniyetleri iki faktörden oluşmuştur. Bu faktörler; dersin işlenişinden memnuniyet ve alt yapı memnuniyeti şeklindedir. Yapılan analiz sonucunda dijital okuryazarlık düzeyinin, uzaktan eğitimde dersin işlenişinden memnuniyet üzerindeki etkisinde uzaktan eğitime yönelik tutumun tam aracı rolüne sahip olduğu ve dijital okuryazarlık düzeyinin, alt yapı memnuniyeti üzerindeki etkisinde uzaktan eğitime yönelik tutumun kısmi aracı rolüne sahip olduğu tespit edilmiştir.

Anahtar Sözcükler: Covid-19, Dijital Okuryazarlık, Uzaktan Eğitim, Memnuniyet, Tutum

Sever S., \& Çatı K., (2021). The mediating role of attitude towards distance education in the effect of digital literacy level on satisfaction with distance education.Journal of Higher Education and Science/Yükseköğretim ve Bilim Dergisi, 11(3), 559-574. https://doi.org/10.5961/jhes.2021.475

Sami SEVER (四)

ORCID ID: 0000-0001-6827-054X

Inonu University, Faculty of Economics and Administrative Sciences, Department of Business Administration, Malatya, Turkey İnönü Üniversitesi, Iktisadi ve Idari Bilimler Fakültesi Işletme Bölümü, Malatya, Türkiye

sami.sever@inonu.edu.tr

Kahraman ÇATI

ORCID ID: 0000-0002-7440-5436

Inonu University, Faculty of Economics and Administrative Sciences, Department of Business Administration, Malatya, Turkey Inönü Üniversitesi, Iktisadi ve Idari Bilimler Fakültesi Işletme Bölümü, Malatya, Türkiye 


\section{INTRODUCTION}

Internet usage rate has been continuously increasing since the 1990s when the internet was invented. According to the results of the Information Technologies Usage Survey on households by Turkish Statistical Institute (TUIK, 2020), the internet usage rate in Turkey has increased by approximately $4 \%$ compared to the previous year and reached $79 \%$ as of 2020 . People quickly meet their various needs in their daily lives by taking advantage of the developments in internet technologies. When the purposes of internet usage are examined, it is seen that the internet is used for various purposes such as reading news, getting information, getting education, shopping, listening to music, finding friends and watching movies. In addition to having an effect that will make life easier, the internet is also possible to be used for malicious purposes. Identity theft, misleading, violation of personal rights, sharing of personal information, and malicious software can be listed as the misuse of the internet. At this point, the concept of digital literacy, which is defined as the competence in accessing digital resources and using them correctly, emerges (Karabacak \& Sezgin, 2019).

Technological developments can be both advantageous and disadvantageous for people. For example, distance education, which has become widespread thanks to technological developments, provides various advantages to people in terms of the use of different learning styles, flexibility, low cost, ease of access to more than one person at the same time, and elimination of geographical and temporal constraints. However, it also has disadvantages in terms of alienation from the discipline of education, difficulties in creating a quality system, technical inadequacies hindering education and security. Despite its various disadvantages, it is possible to state that the pros of distance education are more than the cons (Keleş, 2020). Information is spreading rapidly in the 21st century, which is described as "the Information Age." It is possible to reach a researcher, educator or information needed for daily needs via the internet wherever in the world (Arklan \& Taşdemir, 2013).

The most valuable thing in the world is information. The most important way to obtain information is education and training. In the 21st century, when it is straightforward to access information via the internet, those who will make the best use of this opportunity will undoubtedly be researchers and educators. The most important tool for researchers and educators to reach the required information and to deliver the information to the target audience will be the internet. Therefore, academicians and teachers cannot be expected to remain indifferent to the internet and developments related to the internet (Çalık \& Çınar, 2009).

The widespread use of the internet and the fact that people can handle many jobs more easily and quickly through the internet have caused institutions and organizations to use the internet as a facility to reach their target audiences. Many businesses have started to sell their products on the internet, banks have developed internet and mobile banking for their customers, public institutions have created opportunities on the internet to make transactions easier and the education sector has developed distance education by using the internet. Distance education has generally been developed for people to be able to both work and study or receive education without traveling to other parts of the world. However, the COVID-19 pandemic in the world has made distance education compulsory in Turkey and in the world (Can, 2020).

COVID-19 disease, which was first detected in Wuhan, China, in 2019, spread worldwide in a short time and caused the coronavirus pandemic (WHO, 2019). COVID-19, which affects all areas of life, required a re-evaluation of the education perspective and made applications such as distance education, digital learning, e-learning a necessity (Akçil \& Baştaş, 2021). In order to break the chain of transmission of the disease, which spread very rapidly in this process, face-to-face education was interrupted first and then the Council of Higher Education (CoHE) decided to provide education remotely. In this context, universities had to quickly transform their systems, which they designed for formal education, into a web-based distance education system. Distance education, which is described as webbased education, has begun to be conducted synchronously or asynchronously in universities with this transformation. In this period, it can be said that those who have a high interest in technology will be able to adapt more easily to distance education and e-learning processes (Akçil \& Baştaş, 2021).

Hebebci, Bertiz and Alan (2020) stated that a high level of interaction and social communication could not be easily achieved in distance education as in face-to-face education. Within the scope of the studies, it was stated that the most critical problem of distance education is the lack of interaction when it is evaluated by teachers and faculty members (Barış \& Çankaya, 2016; Chen, Ou, Liu \& Liu, 2001; Jin, 2005). In addition, there are also many studies in the literature showing that perceptions towards online education change positively as the experience of teaching in distance education increases (Alshangeeti, Alsaghier \& Nguyen, 2009; Lloyd, Byrne \& Mccoy, 2012). In addition to all these, many factors such as lack of infrastructure (software, hardware, etc.), economic reasons, technical personnel problem, lack of awareness of the society and especially students on this issue and regional differences in the level of using information technologies are seen as obstacles to distance education (Gökdaş \& Kayri, 2005). It is predicted that some academicians have various deficiencies in the effective use of technological tools, as distance education has been started quickly with the decision of the Council of Higher Education (Altuntaş, Başaran, Özeke \& Yılmaz, 2020). It is essential to understand how these predicted deficiencies cause dissatisfaction among academicians since the satisfaction of employees plays a vital role in the success of an institution (Bayrak Kök, 2010).

In the literature, it is seen that there are studies on the relationships between the variables of digital literacy level, satisfaction with distance education and attitude towards distance education, and there are variables that are related to each other (Amsal et al., 2021; Brinkerhoff \& Koroghlanian, 2005; Hong, 2002; Jan, 2018; Sun et al., 2008). However, no study has been found that considers these variables together and 
reveals whether there is a mediating effect in the relationship between the variables. In this context, it is thought that there is a gap in the literature. When the literature is examined, it is seen that the level of digital literacy is on satisfaction with distance education (Shih, 2006; Wei \& Chou, 2020); digital literacy level is higher than the attitude towards distance education (Ateş \& Altun, 2008; Tang \& Chaw, 2016); it is seen that the attitude towards distance education has an effect on satisfaction with distance education (Prior, Mazanov, Meacheam, Heaslip, \& Hanson, 2016). The level of digital literacy and the attitude towards distance education, which are related to each other, are similarly related to satisfaction with distance education. This led to the assumption that the attitude towards distance education would play an important role in the change in satisfaction with distance education depending on the level of digital literacy. From this point of view, it is assumed that the relationship between digital literacy level and satisfaction with distance education is indirectly based on the attitude towards distance education. Consistent with this assumption, the mediation effect of the attitude towards distance education was tested in the relationship between digital literacy level and satisfaction with distance education. In this context, the study was carried out to determine whether the digital literacy levels of academics, who taught face-to-face education before the COVID-19 pandemic process and continued their education in the form of distance education after the pandemic, have a mediating role in the effect of their attitudes towards distance education on their satisfaction with distance education.

\section{Literature Review}

In the literature, the concept of digital literacy was first discussed by Paul Gilster (Aylin, Yaylak, \& Genç, 2020). Gilster (1997) defined the concept of digital literacy as "the ability to understand different forms of information in the computer environment." Churchill, Ping, Oakley and Churchill (2008) emphasized that digital literacy should not be considered as an alternative to traditional literacy and argued that it is a concept that contributes to general literacy in order to work, learn and socialize in the contemporary world. Gürcan (2011), with a definition similar to Gilster's definition of digital literacy, defined it as "the ability to use large-scale multi-format information provided by computers." Hamutoğlu, Güngören, Uyanık and Erdoğan (2017) stated that digital literacy requires having the ability to use technology actively in reaching the right information, in producing and sharing the right information and in teaching and learning processes in addition to the correct use of different technologies.

Distance education, which is widely used today, first emerged in the 1700s. In Turkey, it was carried out for the first time in 1956 as a teaching activity with letters sent to bank employees (Karatepe, Küçükgençay, \& Peker, 2020). The first usage with the way it is used in today's higher education was in 1982. Open Education Faculty was established in Anadolu University with the Higher Education Law number 2547 and started to admit students in the 1982-83 academic year (Akdemir, 2011). Distance education, which was carried out in various departments of universities from 1982 to 2019 , has begun to be applied in almost all departments in universities with the COVID-19 pandemic (Durak, Çankaya, \& İzmirli, 2020).

In the literature, there are studies in which both the learners and the teachers are involved in evaluating distance education. When the literature is reviewed, it is seen that there are studies that examine students' perspectives (Yağcl, Efendi, \& Akçay, 2019), perceptions (Çiçekdağı, Tekin, \& Tekin, 2013) and attitudes (Ateş \& Altun, 2008; Brinkerhoff \& Koroghlanian, 2005; Harrison, 2020; Karavida, Charissi, \& Tympa, 2021) towards distance education, service quality (Dursun, Oskaybaş, \& Gökmen, 2013) and their epistemological beliefs (Fidan, 2016). In the literature, it is also seen that there are studies that examine students' self-efficacy (Afşar \& Büyükdoğan, 2020), perspectives (Keskin \& Özer Kaya, 2020), problems (Zan \& Zan, 2020) and perceptions (Altuntaş et al., 2020) regarding distance education after COVID-19.

When the results of the studies were examined, Yağcl, Efendi and Akçay (2019) stated in their study on students that face-to-face education was more effective than distance education, contrary to this result, in the study of Çiçekdağı, et al. (2013), students stated that there was no difference in content and quality between distance education and faceto-face education. In another study, it was determined that the most important factor in distance education is teacher quality (Harrison, 2020). In their study, Muilenburg and Berge (2005) expressed the obstacles faced by students in distance education as administrative problems, social interaction, lack of academic skills, technical infrastructure problems, lack of motivation, time constraints, technical problems, internet access and cost. In another study, it was determined that students have concerns about time management and motivation for distance education (Fidalgo, Thormann, Kulyk, \& Lencastre, 2020). Moreover, it was concluded that the quality of service in distance education could not be fully provided (Dursun et al., 2013) and students faced difficulties such as not being able to access technology, not being able to connect to the distance education system, lack of internet, power failure, slow internet connection, high internet fee, lack of communication with the lecturer and indifference (Ilonga, Ashipala, \& Tomas, 2020). In studies conducted after the COVID-19 pandemic, it was determined that students did not have any problems with self-efficacy (Afşar \& Büyükdoğan, 2020) and were satisfied with the distance education system (Altuntaş et al., 2020).

There are various studies in the literature that examine the competencies (Thach \& Murphy, 1995), adaptation processes (Wilson et al., 2003), experiences (Lee \& Busch, 2005), perceptions (Markova, 2021) and opinions (Barış \& Çankaya, 2016; Çetin, Çalışkan, \& Menzi, 2013; İnan, 2013; Kaya, Çitil Akyol, Özbek, \& Pepeler, 2017; Lee \& Busch, 2005; Tuncer \& Tanaş, 2011) of academicians who take active roles in undergraduate and graduate education regarding distance education. It is seen that some studies were conducted to examine the views (Sayan, 2020) and perspectives (Kurnaz \& Serçemeli, 2020) of academicians for distance education carried out after the COVID-19 pandemic. 
When the studies are examined, the most important problem that academicians draw attention to is the lack of interaction in distance education (Barış \& Çankaya, 2016; Çetin et al., 2013; Hebebci et al., 2020; Tuncer \& Tanaş, 2011). In addition, academicians stated that distance education is overshadowed by face-to-face education, that face-to-face education is more efficient than distance education (Kaya et al., 2017; Keskin \& Özer Kaya, 2020) and that workload and stress are higher in distance education (Marek, Chew, \& Wu, 2021). Some studies showed that academicians with online teaching experience approach distance education more moderately than those without experience (Gürer, Tekinarslan, \& Yavuzalp, 2016; Hebebci et al., 2020). Academicians stated that they could not get sufficient technical support and in-service training required for active use of the distance education systems (Durak et al., 2020; Sayan, 2020), they had a negative attitude towards distance education, they lacked digital pedagogical skills and they had a lack of communication (Markova, 2021) especially in the distance education during the COVID-19 pandemic. In addition to these, academicians remarked that students see distance education as a holiday (Sari \& Nayir, 2020), students' attendance and interest in the lesson are low (Gürer et al., 2016) and they are insufficient in motivating students to the lesson due to distance education (Sayan, 2020).

In the literature, it is seen that the level of digital literacy was generally discussed through students (Onursoy, 2018; Prior, Mazanov, Meacheam, Heaslip \& Hanson, 2016), teacher candidates (Aylin et al., 2020; Kozan, 2018; Ocak \& Karakuş, 2018; Üstündağ, Güneş \& Bahçivan, 2017), teachers (Arslan, 2019; Korkmaz, 2020) and academicians (Uzun \& Çelik, 2020). In the literature, it was examined whether the digital literacy variable has a relationship with variables such as disposition to lifelong learning (Özoğlu, 2019), performance in distance education, educational continuity (Mohammadyari \& Singh, 2015), financial literacy level (Ağaç, 2020), internet addiction (Kul, 2020), online learning behavior (Prior et al., 2016), digital narrative (Churchill et al., 2008), health literacy (Yeşildal, 2018) and sensitivity to cyber bullying (Kozan, 2018). In addition to these studies, Maphosa and Bhebhe (2019) emphasized that digital literacy is very important for distance education because of the advantages of research, study, analysis and comparison at any time. Karabacak and Sezgin (2019) tried to reveal the position of digital transformation in higher education in Turkey through digital literacy in their study. Drawing attention to the fact that digital literacy education should take place in almost all departments of universities, they stated that these courses will be an important step for digital transformation. However, this suggestion raises a variety of questions. Who will teach digital literacy lessons and how the digital literacy levels of academicians are, are the questions that come to mind after this suggestion.

In the literature, there are various studies discussing the factors affecting satisfaction in the education sector and the variables that may be associated with satisfaction (Amsal, Lusia, Febri, Mellyna, \& Yan, 2021; Dalgar, Alparslan, \& Sungur, 2017; Korucuk, 2020; Murat \& Çevik, 2008; Özdemir \& Gürbüz, 2020;
Sun, Tsai, Finger, Chen, \& Yeh, 2008; Wei \& Chou, 2020). When the studies were examined, satisfaction in education was tried to be measured over various dimensions such as "management and organizational structure", "socio-culture and health", "education", "physical and technical conditions", "academic conditions" and "communication" (Murat \& Çevik, 2008), "management and organization", "education", "research", "infrastructure" and "relations with stakeholders" (Özdemir \& Gürbüz, 2020), "peace in department", "positive relations with senior management", "positive relations with department manager", "the attitude of senior management to encourage academic studies", "administrative service", "physical and technical infrastructure" and "socio-cultural infrastructure" (Dalgar et al., 2017). In studies on satisfaction with distance education, it was determined that "computer skills", "learning motivations" (Wei \& Chou, 2020), "interactive learning" and "perceived usefulness of distance education" (Amsal et al., 2021) have a significant effect on satisfaction with distance education.

The academicians were not included in the studies focusing on digital literacy levels and satisfaction. Moreover, the studies in which academicians were highly included on the evaluation of distance education, were conducted in periods when distance education was used less compared to face-to-face education. Due to the COVID-19 pandemic, the distance education system has started to be used in all universities. This system change was made very quickly and relatively unplanned. In this context, this study will be critical in evaluating the states of satisfaction experienced by academicians regarding the process. Thanks to this study, administrators will have the opportunity to see how academic staff evaluate the process, what the deficiencies are, whether academicians' digital literacy levels have an effect on their satisfaction and whether their attitudes towards distance education have a role in this effect. It is thought that the results of this study will be important in the applications and decisions to be taken in the next period.

\section{METHOD}

\section{Research Model and Hypotheses}

This study aims to measure the mediating effect and reveal the indirect effect. In a simple causality relationship, it was emphasized whether the independent variable $X$ affects the dependent variable $Y$. Until recently, academic studies have focused on which dependent variable changes depending on which independent variables. However, it is seen that the academicians mostly focused on indirect effect after the mediating effect measurement method, developed by Baron and Kenny (1986). It is seen that 99,756 citations were made to the study of Baron and Kenny (1986) at Google Scholar until March 14,2021 . This is a clear indicator of the importance given to indirect effect analysis in academic studies.

In the mediating effect, it is emphasized that the effect of the independent variable $X$ on the dependent variable $Y$ is due to another variable (mediating variable). In other words, in order to change the dependent variable $Y$, instead of only the dependent variable $X$, it is necessary to consider other mediating or moderating variables. 
In this study, it would not be correct to consider only digital literacy levels in order to increase the satisfaction of academicians with distance education. In addition, it will be important to reveal whether another variable is effective in the effect of academicians' digital literacy levels (dependent variable $\mathrm{X}$ ) on their satisfaction with distance education (dependent variable Y). Therefore, the model of the study was constructed as the mediating effect of the attitude towards distance education (M) in the effect of the independent variable digital literacy level $(X)$ on the dependent variable level of satisfaction with distance education $(\mathrm{Y})$.

When the literature is examined, it is seen that the level of digital literacy is on satisfaction with distance education (Shih, 2006; Wei \& Chou, 2020); digital literacy level is higher than the attitude towards distance education (Ateş \& Altun, 2008; Tang \& Chaw, 2016); it is seen that the attitude towards distance education has an effect on satisfaction with distance education (Prior, Mazanov, Meacheam, Heaslip, \& Hanson, 2016). These studies show that the level of digital literacy is the precursor of the attitude towards distance education, and both concepts are also the precursors of satisfaction with distance education. From this point of view, whether there is a mediating effect was tested using the method introduced by Baron and Kenny (1986). According to the approach of Baron and Kenny (1986), the existence of a mediating effect is decided at the end of four steps. These steps;

1. The independent variable $(X)$ should significantly affect the dependent variable $(\mathrm{Y})$. This is path $\mathrm{c}$.

2. The independent variable $(X)$ should significantly affect the mediating variable (M). This is path a.

3. When the effect of the independent variable $(X)$ and the mediating variable $(M)$ together on the dependent variable is measured, the effect of the mediating variable on the dependent variable is path $b$ and the effect of the independent variable on the dependent variable is $c^{\prime}$ path. As a result of the analysis, if the path $c^{\prime}$ is found to be statistically insignificant, it is possible to talk about the complete mediation effect and if the regression coefficient of the path $c^{\prime}$ is smaller than the regression coefficient of the path $c$, it is possible to talk about the partial mediation effect.

4. In Baron and Kenny (1986)'s method, after the steps mentioned above to show whether the indirect effect is significant or not, the Sobel test is used to determine whether there is an indirect effect (Gürbüz, 2019; Hayes, 2009; Zhao, Lynch \& Chen, 2010: 198).

Researchers who defend the contemporary method (Gürbüz, 2019; Hayes, 2009; Zhao, et al., 2010) argue that Baron and Kenny (1986)'s method involves a long process. In Baron and Kenny (1986)'s method, the results of hypothesis testing regarding path $a$ and $b$ do not provide additional information about the extent or significance of the indirect effect beyond the Sobel test. Therefore, it is not correct to attribute the use of the Sobel test to the results of the regression analysis linking $X$ to $\mathrm{M}$ or M to Y (Hayes 2009; Hayes \& Rockwood, 2017). One of the most important criticisms of the contemporary approach is the use of the Sobel test in Baron and Kenny (1986)'s method. Although the Sobel test is based on the normal distribution assumption, axb does not show a normal distribution, but it can approach the normal distribution in large samples (Preacher \& Selig, 2012; Stone \& Sobel, 1990). There are alternative tests that perform better than the Sobel test (Hayes \& Scharkow, 2013). As an alternative test, Bootstrap confidence intervals (Shrout \& Bolger, 2002: 424), Monte Carlo confidence intervals (Biesanz, Falk, \& Savalei, 2010) and Bayesian credible intervals (Wang \& Preacher, 2015) can be said. Bootstrap confidence interval test has become more common with the effect of developed macros (Hayes \& Rockwood 2017: 44).

This study was conducted to determine whether the attitudes towards distance education have a mediating role in the effect of academicians' digital literacy levels on their satisfaction with distance education.

The research model is as shown in Figure 2.

The research hypotheses suitable for the model are as follows;

H1: Academicians' digital literacy levels affect their attitudes towards distance education.

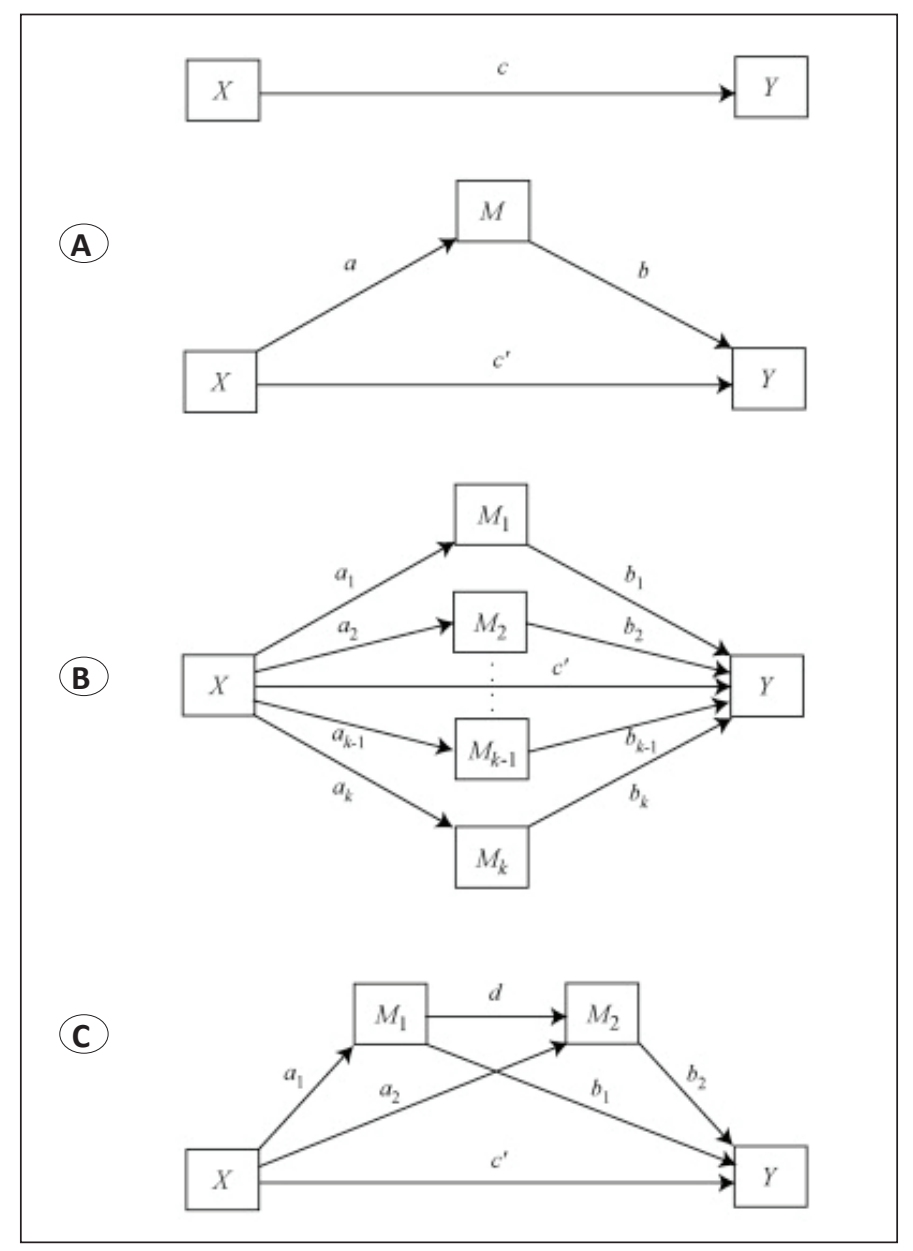

Figure 1: Mediation test model (Hayes \& Rockwood, 2017). 


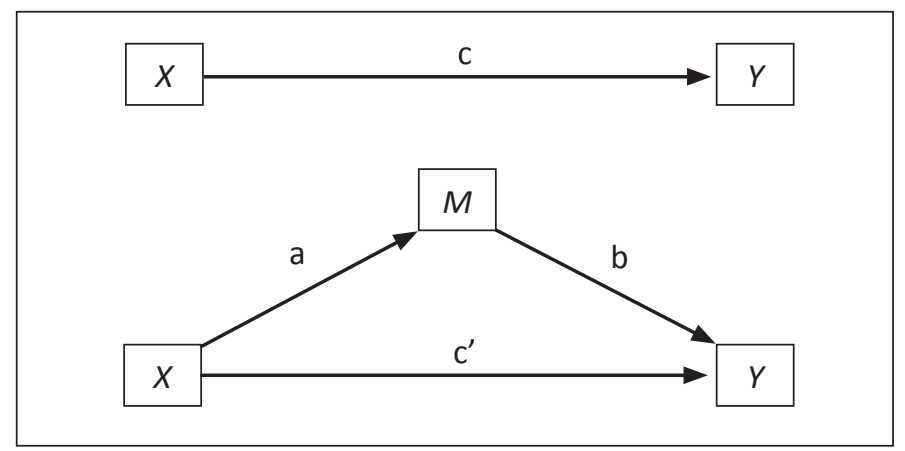

Figure 2: The research model.

H2: Academicians' digital literacy levels affect their satisfaction with distance education.

H2,a: Academicians' digital literacy levels affect their satisfaction with the teaching of the course in distance education.

$\mathrm{H} 2$, b: Academicians' digital literacy levels affect their satisfaction with the technical infrastructure in distance education.

H3: Academicians' attitudes towards distance education affect their satisfaction with distance education.

H3,a: Academicians' attitudes towards distance education affect their satisfaction with the teaching of the course in distance education.

H3,b: Academicians' attitudes towards distance education affect their satisfaction with the technical infrastructure in distance education.

H4: Academicians' attitudes towards distance education have a mediating role in the effect of their digital literacy levels on satisfaction.

H4,a: Academicians' attitudes towards distance education have a mediating role in the effect of their digital literacy levels on their satisfaction with the teaching of the course in distance education.

$\mathrm{H} 4, \mathrm{~b}$ : Academicians' attitudes towards distance education have a mediating role in the effect of their digital literacy levels on their satisfaction with the technical infrastructure in distance education.

\section{Research Population and Sample}

This study, which was carried out with academicians teaching at Inonu University, was conducted between January 1-31, 2021. In order to determine the size of the research population, the faculties in Inonu University were filtered according to the academic search website of the Council of Higher Education. As a result of filtering, 1378 academicians were determined as the population of the research. According to the table prepared by Sekaran (2003), a sample size of 302 is sufficient for a study with a population of 1400 .

The research data were collected with a questionnaire created by using the scales in the literature. The questionnaire developed online within the scope of the research was sent to all academicians via e-mail. Since there was not enough return in the first time, the questionnaire was sent to all academicians for the second time after 10 days. After the second e-mail, a total of 341 academicians responded to the questionnaire. Analyzes were performed on the data of 341 questionnaires.

\section{Data Collection Tools}

The Scale of Digital Literacy Competency, the Scale of Attitude towards Distance Education and the Scale of Satisfaction with Distance Education were used to collect data in the study.

In measuring the digital literacy levels of academicians, the 5-point Likert (1=Strongly Disagree, 2=Disagree, 3=Undecided, 4=Agree, 5=Strongly Agree) scale used by Üstündağ, et al. (2017) in their study was used. There are 10 items in the scale in total.

In measuring the attitudes of academicians towards distance education, the 5-point Likert (1=Strongly Disagree, 2=Disagree, 3=Undecided, 4=Agree, 5=Strongly Agree) scale used by Koloğlu (2016) and Gök and Kılıç Çakmak (2020) in their studies was used. There are 9 items in the scale in total.

In measuring the satisfaction levels of academicians with distance education, the 5-point Likert (1=Strongly Disagree, 2=Disagree, $3=$ Undecided, 4=Agree, 5=Strongly Agree) scales under the titles of satisfaction with the teaching of the course and satisfaction with the infrastructure of the questionnaire used by Istanbul Arel University (2020) to determine the satisfaction levels of academicians with distance education were used.

\section{Data Analysis}

The data collected online in the study were encoded and transferred to the SPSS software. In order to determine whether parametric tests can be used to test the hypotheses established in the study, the data were tested for normality. As a result of the normality test for the scales, it was determined that the skewness and kurtosis values were within \pm 1.5 limits. According to Tabachnick and Fidell (2013), the skewness and kurtosis values within \pm 1.5 limits indicate that the data are normally distributed. Based on this result, parametric analysis techniques were employed. Frequency, correlation, regression, Hayes mediation and Sobel tests were used to analyze the data.

Findings

Within the scope of the research, findings regarding the digital literacy levels of the academicians, their satisfaction with distance education, their attitudes towards distance education and the relations between them were revealed.

\section{Findings Regarding Demographic Characteristics}

Descriptive statistical information about the sample included in the study is given in Table 1.

When Table 1 is examined, it is seen that $64.2 \%$ of the participants in the study are males and $35.8 \%$ are females. In terms of age distribution, it is seen that $10.3 \%$ of the participants are 
Table 1: Distribution of the Demographic Characteristics of the Participants

\begin{tabular}{|c|c|c|c|c|c|}
\hline Demographic Characteristic & Frequency & Ratio (\%) & Demographic Characteristic & Frequency & Ratio (\%) \\
\hline Gender $(n=341)$ & & & Faculty $(n=341)$ & & \\
\hline Female & 122 & 35.8 & Dentistry & 11 & 3.2 \\
\hline Male & 219 & 64.2 & Pharmacy & 7 & 2.1 \\
\hline Age $(n=341)$ & & & Education & 57 & 16.7 \\
\hline $20-30$ & 35 & 10.3 & Science and Literature & 49 & 14.4 \\
\hline $31-40$ & 109 & 32.0 & Fine Arts & 7 & 2.1 \\
\hline $41-50$ & 103 & 30.2 & Nursing & 10 & 2.9 \\
\hline $51-60$ & 70 & 20.5 & Law & 10 & 2.9 \\
\hline 61 and over & 24 & 7.0 & Economics and Administrative Sciences & 54 & 15.8 \\
\hline Marital Status $(n=341)$ & & & Theology & 30 & 8.8 \\
\hline Single & 72 & 21.1 & Communication & 12 & 3.5 \\
\hline Married & 269 & 78.9 & Engineering & 27 & 7.9 \\
\hline Titles ( $n=341)$ & & & Health Sciences & 8 & 2.3 \\
\hline Res. Asst. & 53 & 15.5 & Sport Sciences & 10 & 2.9 \\
\hline Lecturer & 24 & 7.0 & Medicine & 49 & 14.4 \\
\hline Asst. Prof. & 89 & 26.1 & Type of Teaching $(n=341)$ & & \\
\hline Assoc. Prof. & 71 & 20.8 & Synchronous & 254 & 74.5 \\
\hline Prof. & 104 & 30.5 & Asynchronous & 87 & 25.5 \\
\hline Professional Experience $(n=341)$ & & & Experience in Distance Education $(n=341)$ & & \\
\hline 5 years and less & 48 & 14.1 & Yes & 140 & 41.1 \\
\hline $6-10$ years & 61 & 17.9 & No & 201 & 58.9 \\
\hline $11-15$ years & 48 & 14.1 & & & \\
\hline $16-20$ years & 38 & 11.1 & & & \\
\hline More than 20 years & 146 & 42.8 & & & \\
\hline
\end{tabular}

$20-30$ years old, $32 \%$ of them are $31-40$ years old, $30.2 \%$ are $41-50$ years old, $20.5 \%$ are $51-60$ years old and $7 \%$ are 61 years and older. $21.1 \%$ of the participants are single and $78.9 \%$ are married. It is seen that $15.5 \%$ of the participants are research assistants, 7\% are lecturers, $26.1 \%$ are assistant professors, $20.8 \%$ are associate professors and $30.5 \%$ are professors. In terms of professional experience of the participants, $14.1 \%$ of the participants have less than 5 years of experience, $17.9 \%$ have $6-10$ years, $14.1 \%$ have $11-15$ years, $11.1 \%$ have $16-20$ years and $42.8 \%$ have more than 20 years of experience. It is seen that there are participants from all 14 faculties of Inonu University. It is seen that the highest level of participation is in the Faculty of Education with a rate of $16.7 \%$. This is followed by the Faculty of Economics and Administrative Sciences with a rate of $15.8 \%$ and the Faculty of Science and Literature and the Faculty of Medicine with the rates of $14.4 \%$. It is seen that $74.5 \%$ of the participants teach synchronously and $25.5 \%$ asynchronously. In terms of experience in distance education, it is seen that $41.1 \%$ of the participants had experience in distance education before the pandemic and $58.9 \%$ did not have experience in distance education before the pandemic. To make a general evaluation, it can be said that the great majority of the participants are experienced academicians, the courses in distance education are mostly conducted synchronously and most of the academicians who are highly experienced in faceto-face education did not have experience in distance education before the COVID-19 pandemic.

\section{Findings Regarding Factor Analysis}

In this part, findings regarding the exploratory factor analysis performed for the scales used within the scope of the research will be included.

The Kaiser-Meyer-Olkin Measure and Barlett test results for the Digital Literacy Sufficiency Level variable show that the data are sufficient for factor analysis (KMO value: .937, Bartlett's test $p$ $<0.001$ ). As a result of the exploratory factor analysis, it was determined that the data were suitable for the single factor structure of the scale and the factor loadings were found to be between 0.614 and 0.875 . It was determined that this single factor explained $61.8 \%$ of the total variance. In single-factor scales, it is considered sufficient for the explained variance to be $30 \%$ or more (Büyüköztürk, 2018: 135).

The Kaiser-Meyer-Olkin Measure and Barlett test results for the Attitude Towards Distance Education variable show that the data are sufficient for factor analysis (KMO value: .915, 
Bartlett's test $p<0.001)$. As a result of the exploratory factor analysis, it was determined that the data were suitable for the single factor structure of the scale and the factor loadings were found to be between 0.671 and 0.866 . It has been found that this single factor is sufficient because it explains $60.3 \%$ of the total variance and is over 30\% (Büyüköztürk, 2018: 135).

The Kaiser-Meyer-Olkin Measure and Barlett test results on the satisfaction with distance education variable show that the data are sufficient for factor analysis (KMO value: .863, Bart- lett's test $p<0.001)$. As a result of the factor analysis, it was determined that the items were suitable for the 2 -factor structure. These factors were named as satisfaction with teaching ( 6 items) and satisfaction with technical infrastructure (6 items). The first factor explained $39.21 \%$ of the total variance in the scale and the second factor explained $18.971 \%$. Both factors together explained $58.181 \%$ of the total variance. The fact that the explained variance is high indicates that satisfaction with distance education is well measured (Büyüköztürk, 2018: 136).

Table 2: Factor Analysis Results for the Digital Literacy Competency Level

\section{Items}

\section{Loading}

Eigenvalue

\begin{tabular}{|l|l|}
\hline & 6.180 \\
.808 & \\
.843 & \\
.814 & \\
.847 & \\
.875 & \\
.829 & \\
.765 & \\
.706 & \\
.723 & \\
.614 &
\end{tabular}

Variance \%

Digital Literacy Competency Level

I can solve the technical problems I encounter in information and communication technologies in daily life by myself.

I can easily learn to use new information and communication technologies.

I follow new information and communication technologies.

I have knowledge of many different information and communication technologies.

I have the technical skills required to use information and communication technologies for learning purposes.

I have the technical skills required to use information and communication technologies for teaching purposes.

The skills I have in information and communication technologies are sufficient.

I have search skills to obtain information from the web.

Internet security, web search and internet fraud etc. I am familiar with the issues.

In my studies, I help my friends over the internet.

Kaiser-Meyer-Olkin sampling adequacy: 0.937, Bartlett's test of sphericity: $X^{2}: X^{2}: 2274.874$,

Degree of freedom (df): 45, Significance level (p): .000, Total variance explained: \%61.796

Table 3: Factor Analysis Results for the Attitude towards Distance Education

\begin{tabular}{|c|c|c|c|}
\hline Items & Loading & Eigenvalue & Variance \% \\
\hline Attitude towards Distance Education & & 5.427 & 60.296 \\
\hline Distance education is more effective than face-to-face education. & .753 & & \\
\hline In distance education, the level of participation of students in the course is high. & .671 & & \\
\hline Distance education is the future education model. & .746 & & \\
\hline Distance education provides equal opportunity in education. & .713 & & \\
\hline I want distance education to continue. & .850 & & \\
\hline $\begin{array}{l}\text { The learning outcomes of distance education are equivalent to face-to-face } \\
\text { education. }\end{array}$ & .844 & & \\
\hline With distance education, the quality of education increases. & .866 & & \\
\hline $\begin{array}{l}\text { I believe that distance education will be preferred more than traditional education } \\
\text { in the future. }\end{array}$ & .745 & & \\
\hline $\begin{array}{l}\text { My experiences in distance education have changed my perspective on distance } \\
\text { education in a positive way. }\end{array}$ & .777 & & \\
\hline
\end{tabular}

Kaiser-Meyer-Olkin sampling adequacy: 0.915, Bartlett's test of sphericity: $X^{2}$ : 1862.457 ,

Degree of freedom (df): 36, Significance level (p): .000, Total variance explained: \%60.296 


\section{Findings Regarding Reliability, Correlation, Regression and Tests of Mediating Variables}

When Table 5 is examined, it is seen that there are mean, standard deviation, reliability and correlation values for the variables analyzed within the scope of the study. In the reliability analysis performed after the factor analysis, the internal consistencies of the scales were examined first. As a result of the analysis, it is seen that the Cronbach Alpha values for the variables are above 0.70 , which is the minimum acceptable value (Coşkun, Altunışık and Yıldırım, 2019: 149). Therefore, it can be stated that the reliability of the scale is high. When the correlation analysis results are examined, it is seen that there are positive and significant relationships between the variables of digital literacy level, attitude towards distance education, satisfaction with teaching in distance education and satisfaction with infrastructure. When the means of the responses given for the variables are examined, it is seen that the highest level of agreement is in the variable of "digital literacy level". It is seen that the second highest level of agreement is in the variable of "satisfaction with infrastructure", followed by the variable of "satisfaction with teaching". It is seen that the lowest level of agreement is in the variable of "attitude towards distance education".

Table 4: Factor Analysis Results for the Variable of Satisfaction with Distance Education

Factors

\section{Satisfaction with Teaching (6 items)}

During the pandemic, I can reach students more easily and communicate in the distance education system.

In general, I prefer to teach in the distance education system.

During the pandemic, the flexible working conditions provided by the distance education system increased my efficiency.

During the pandemic, students' interest in lessons was higher in the distance education system.

I am satisfied with the lesson planning in the distance education system during the pandemic.

During the pandemic, class periods in the distance education system are sufficient.

\section{Satisfaction with Infrastructure (6 items)}

I did not experience any connection problems in the distance education system due to the internet infrastructure in the area where I was teaching.

In the distance education system, I did not experience a connection problem due to the system in the courses.

I am satisfied with the sound and image quality of the distance education system.

I think the distance education software is easy to use.

I could easily convey my problems about the distance education system.e

In the distance education system, I did not experience a connection problem because of my device in my courses.

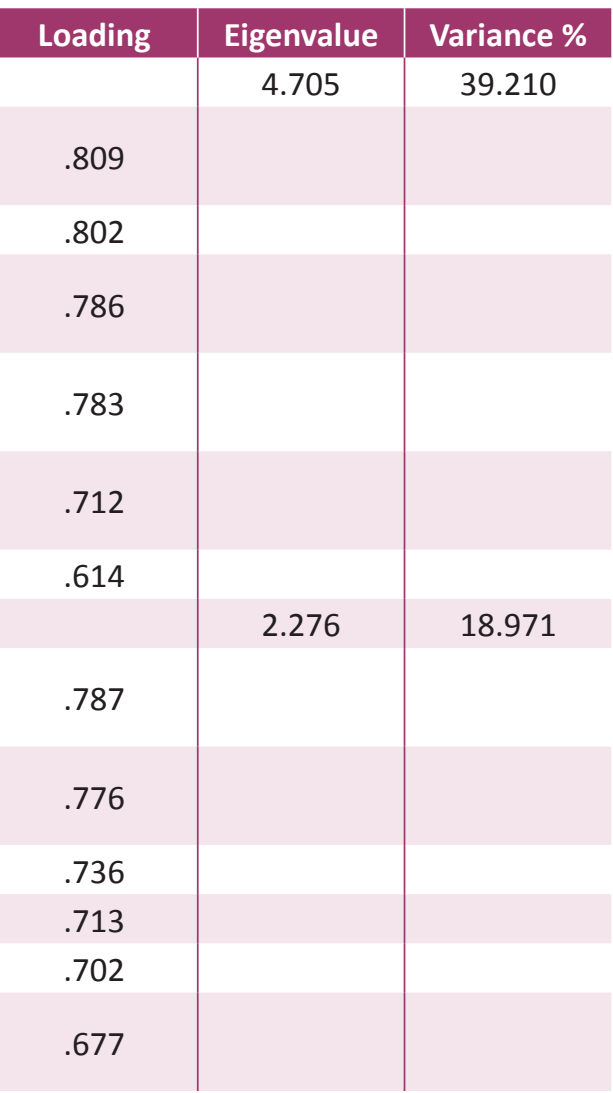

Kaiser-Meyer-Olkin sampling adequacy: 0.863, Bartlett's test of sphericity: $X^{2}: 1734.972$, Degree of freedom (df): 66, Significance level (p): .000, Total variance explained: \% 58.181

Table 5: Mean, Standard Deviation, Reliability and Correlations for the Variables

\begin{tabular}{|c|c|c|c|c|c|c|c|c|}
\hline \multirow{2}{*}{ Variables } & \multirow{2}{*}{ Mean } & \multirow{2}{*}{$\begin{array}{l}\text { Standard } \\
\text { Deviation }\end{array}$} & \multirow{2}{*}{$\begin{array}{c}\text { Coefficient } \\
\text { Alpha }\end{array}$} & \multirow{2}{*}{$\begin{array}{l}\text { Number } \\
\text { of items }\end{array}$} & \multicolumn{4}{|c|}{ Correlation } \\
\hline & & & & & DLL & ADE & ST & SI \\
\hline Digital Literacy Level (DLL) & 3.73 & 0.75 & 0.93 & 10 & 1 & & & \\
\hline Attitude towards Distance Education (ADE) & 2.20 & 0.87 & 0.91 & 9 & $.226^{* *}$ & 1 & & \\
\hline Satisfaction with Teaching (ST) & 2.66 & 0.88 & 0.86 & 6 & $.211^{* *}$ & $.806^{* *}$ & 1 & \\
\hline Satisfaction with Infrastructure (SI) & 3.32 & 0.87 & 0.84 & 6 & $.193^{* *}$ & $.254^{* *}$ & $.357^{* *}$ & 1 \\
\hline
\end{tabular}

** $p<0.01$. 
Table 6: Regression Analysis Results for the Variables

\begin{tabular}{c|c|c|c|c|c|c|c} 
Hypothesis & $\begin{array}{c}\text { Independent } \\
\text { Variable }\end{array}$ & $\begin{array}{c}\text { Dependent } \\
\text { Variable }\end{array}$ & $\begin{array}{c}\text { Standardized } \\
\text { Beta }\end{array}$ & $\begin{array}{c}\text { Adjusted } \\
\mathbf{R}^{2}\end{array}$ & $\mathbf{F}$ & $\mathbf{P}$ & $\begin{array}{c}\text { Accepted/ } \\
\text { Rejected }\end{array}$ \\
\hline $\mathrm{H}_{1}$ & $\mathrm{DLL}$ & $\mathrm{ADE}$ & .226 & .048 & 18.302 & $.000^{*}$ & Accepted \\
$\mathrm{H}_{2}, \mathrm{a}$ & $\mathrm{DLL}$ & $\mathrm{ST}$ & .211 & .042 & 15.755 & $.000^{*}$ & Accepted \\
$\mathrm{H}_{2}, \mathrm{~b}$ & $\mathrm{DLL}$ & $\mathrm{SI}$ & .193 & .034 & 13.055 & $.000^{*}$ & Accepted \\
$\mathrm{H}_{3^{\prime}} \mathrm{a}$ & $\mathrm{ADE}$ & $\mathrm{ST}$ & .806 & .649 & 630.245 & $.000^{*}$ & Accepted \\
$\mathrm{H}_{3}, \mathrm{~b}$ & $\mathrm{ADE}$ & $\mathrm{SI}$ & .254 & .062 & 23.293 & $.000^{*}$ & Accepted \\
\hline
\end{tabular}

$*: p<0.05$.

The fact that the $p$ values in Table 6 are less than 0.05 indicates that the relationships between dependent and independent variables are significant. In other words, in this table, the linear relationships between academicians' attitudes towards distance education, satisfaction with teaching and satisfaction with infrastructure (dependent variables) and digital literacy levels (independent variable) and the linear relationships between academicians' satisfaction with teaching and satisfaction with infrastructure in distance education (dependent variables) and their attitudes towards distance education (independent variable) are statistically significant. Both $\mathrm{p}$ and $\mathrm{F}$ values show that regression models are significant. According to these results;

The hypothesis " $\mathrm{H} 1$ : Academicians' digital literacy levels affect their attitudes towards distance education" is accepted. The $B$ coefficient for the variable of digital literacy level is 0.226 . In other words, a one-unit increase in the variable of digital literacy level increases the variable of attitude towards distance education by 0.226 units.

The hypothesis “ $\mathrm{H} 2$,a: Academicians' digital literacy levels affect their satisfaction with teaching in distance education" is accepted. The $B$ coefficient for the variable of digital literacy level is 0.211. In other words, a one-unit increase in the variable of digital literacy level increases the variable of satisfaction with teaching by 0.211 units.

The hypothesis ' $\mathrm{H} 2, \mathrm{~b}$ : Academicians' digital literacy levels affect their satisfaction with infrastructure in distance education" is accepted. The B coefficient for the variable of digital literacy level is 0.193 . In other words, a one-unit increase in the variable of digital literacy level increases the variable of satisfaction with infrastructure by 0.193 units.

The hypothesis “H3,a: Academicians' attitudes towards distance education affect their satisfaction with teaching in distance education" is accepted. The $\beta$ coefficient for the variable of attitude towards distance education is 0.806 . In other words, a one-unit increase in the variable of attitude towards distance education increases the variable of satisfaction with teaching in distance education by 0.806 units.

The hypothesis “ $\mathrm{H} 3, \mathrm{~b}$ : Academicians' attitudes towards distance education affect their satisfaction with infrastructure in distance education" is accepted. The ß coefficient for the variable of attitude towards distance education is 0.254 . In other words, a one-unit increase in the variable of attitude towards distance education increases the variable of satisfaction with technical infrastructure in distance education by 0.254 units.

A regression analysis consisting of 4 steps was performed for the mediating effect of the attitude towards distance education in the effect of digital literacy on satisfaction. In this method, in order for a variable to be considered as a mediating variable, it must meet the following conditions (Karagöz, 2019):

1. The independent variable (DLL) must have an effect on the dependent variable (SDE).

2. The independent variable (DLL) must have an effect on the mediating variable (ADE).

3. The mediating variable (ADE) must have an effect on the dependent variable (SDE).

4. When the mediating variable (ADE) is included in the model with the independent variable (DLL), the effect of the independent variable (DLL) on the dependent variable (SDE) must either be insignificant or decrease. If the effect of the independent variable (DLL) on the dependent variable (SDE) is insignificant, complete mediation effect can be mentioned, if its effect decreases, partial mediation effect can be mentioned (Yener, 2017: 200).

When the results of the regression analysis in Table 6 are examined, it is seen that the first 3 conditions stated above are met. The Process plugin v2.16 for SPSS was used to test whether the 4 th condition is met or not. Therefore, the $\mathrm{H} 4$, a and $\mathrm{H} 4, \mathrm{~b}$ hypotheses, in which the attitude towards distance education is the mediating variable, was tested using the Process plugin v2.16 for SPSS. The results for the $\mathrm{H} 4$, a hypothesis are given in Table 7 and the results for $\mathrm{H} 4, \mathrm{~b}$ in Table 8.

When Table 7 is examined, it is seen that with the inclusion of ADE in the model, the coefficient of DLL decreases from 0.2481 to 0.035 and its effect on the dependent variable (satisfaction) with ADE becomes insignificant $(0.3676>0,05)$. According to these results, it is possible to mention a complete mediation effect.

Mediating effect can also be tested according to Boot LLCl and Boot $\mathrm{ULCl}$ values. If value of 0 is not between Boot $\mathrm{LLCl}$ and Boot ULCl values, it is stated that there is a mediating effect in the relationship between the dependent variable and the 
Table 7: Results of Mediating Effect Analysis for H4, a Hypothesis

\begin{tabular}{|c|c|c|c|c|c|c|}
\hline \multicolumn{7}{|c|}{ Dependent Variable: ADE } \\
\hline & Coefficient & Standard Error & $\mathbf{t}$ & p & LLCI & ULCI \\
\hline Constant & 1.2242 & 0.2337 & 5.2379 & 0.0000 & 0.7645 & 1.6840 \\
\hline DLL & 0.2631 & 0.0615 & 4.2781 & 0.0000 & 0.1421 & 0.3841 \\
\hline \multicolumn{7}{|c|}{ Dependent Variable: ST } \\
\hline & Coefficient & Standard Error & $\mathbf{t}$ & p & LLCI & ULCI \\
\hline Constant & 0.7488 & 0.1495 & 5.0099 & 0.0000 & 0.4548 & 1.0428 \\
\hline ADE & 0.8098 & 0.0334 & 24.2423 & 0.0000 & 0.7441 & 0.8755 \\
\hline DLL & 0.0350 & 0.0388 & 0.9022 & 0.3676 & -0.0413 & 0.1114 \\
\hline \multicolumn{7}{|c|}{ Dependent Variable: ST } \\
\hline & Coefficient & Standard Error & $t$ & $p$ & LLCI & ULCI \\
\hline Constant & 1.7402 & 0.2376 & 7.3255 & 0.0000 & 1.2729 & 2.2075 \\
\hline DLL & 0.2481 & 0.0625 & 3.9692 & 0.0001 & 0.1251 & 0.3710 \\
\hline \multicolumn{7}{|c|}{ Completely Standardized Indirect Effect of DLL on ST } \\
\hline & Effect & Boot SE & Boot LLCI & Boot ULC & \multirow{4}{*}{\multicolumn{2}{|c|}{$\mathrm{H}_{4}, \mathrm{a}:$ Accepted }} \\
\hline ADE & 0.1810 & 0.0419 & 0.0940 & 0.2580 & & \\
\hline \multirow[t]{2}{*}{ Sobel Test } & Effect & Standard Error & $\mathbf{z}$ & $\mathbf{p}$ & & \\
\hline & 0.2131 & 0.0506 & 4.2095 & 0.0000 & & \\
\hline
\end{tabular}

p<0.05, SE: Standard Error, CI: Confidence Interval.

independent variable (Adıgüzel, Çakir and Atalay, 2021: 139). When Table 7 is examined, it is possible to mention the existence of a mediating variable (ADE) effect in the relationship between the dependent variable (ST) and the independent variable (DLL), since there is no value of 0 between Boot $\mathrm{LLCl}$ (0.0940) and Boot ULCI (0.2580) values. According to the analysis, the complete mediation role of the attitude towards distance education was discovered. It is seen that the significance ( $p: 0.3676>0.05$ ) disappears besides the decrease in the effect coefficient of the independent variable on the dependent variable. According to the results of the Sobel test (Sobel, 1982: 292) performed to determine whether the effect level of the mediating variable role is statistically significant, it is seen that the mediating effect of the attitude towards distance education $(z=4.2095, p<0.05)$ is significant. According to these results, the hypothesis “ $\mathrm{H} 4$,a: Academicians' attitudes towards distance education have a mediating role in the effect of their digital literacy levels on their satisfaction with the teaching of the courses in distance education " is accepted.

When the effect of DLL (independent variable) alone on SI (dependent variable) is examined in Table 8 , it is seen that the effect level is significant $(P<0.05)$ and the coefficient is 0.2229 . When the mediating variable ADE is included in the analysis, it is seen that the effect of DLL (independent variable) on SI (dependent variable) is still significant $(0.0081<0.05)$, but there is a decrease (from 0.2229 to 0.1649 ) in the coefficient. In other words, the effect of the independent variable (DLL) on the dependent variable (SI) decreases with the inclusion of the mediating variable (SI) in the analysis. Therefore, it is possible to mention a partial mediation.

According to the results of the Sobel test to determine whether the effect level of the mediating variable role is statistically significant, it is seen that the mediating effect of the attitude towards distance education $(z=2.9339, p<0.05)$ is significant. According to these results, the hypothesis " $\mathrm{H} 4, \mathrm{~b}$ : Academicians' attitudes towards distance education have a mediating role in the effect of their digital literacy levels on their satisfaction with the infrastructure" is accepted.

\section{CONCLUSION and DISCUSSION}

In this study, the effect of the digital literacy levels of the academicians who gave lectures face-to-face before the COVID-19 pandemic and continued their teaching in distance education during the pandemic on their satisfaction in distance education and the role of their attitudes towards distance education on this effect were examined. The study was conducted on the basis of three variables: "digital literacy level", "attitude towards distance education" and "satisfaction with distance education". When the findings regarding the variables are examined, while the scales of "digital literacy level" and "attitude towards distance education" are one-dimensional, the scale of "satisfaction with distance education" is two-dimensional, namely satisfaction with teaching and infrastructure. According to the means of the responses given to the variables, it is seen 
Table 8: Results of Mediating Effect Analysis for H4,b Hypothesis

\begin{tabular}{|c|c|c|c|c|c|c|}
\hline \multicolumn{7}{|c|}{ Dependent Variable: ADE } \\
\hline & Coefficient & Standard Error & $\mathbf{t}$ & $\mathbf{p}$ & LLCl & ULCI \\
\hline Constant & 1.2242 & 0.2337 & 5.2379 & 0.0000 & 0.7645 & 1.6840 \\
\hline DLL & 0.2631 & 0.0615 & 4.2781 & 0.0000 & 0.1421 & 0.3841 \\
\hline \multicolumn{7}{|c|}{ Dependent Variable: SI } \\
\hline & Coefficient & Standard Error & $\mathbf{t}$ & p & LLCI & ULCI \\
\hline Constant & 2.2157 & 0.2382 & 9.3025 & 0.0000 & 1.7472 & 2.6842 \\
\hline ADE & 0.2204 & 0.0532 & 4.1400 & 0.0000 & 0.1157 & 0.3251 \\
\hline DLL & 0.1649 & 0.0619 & 2.6652 & 0.0081 & 0.0432 & 0.2867 \\
\hline \multicolumn{7}{|c|}{ Dependent Variable: SI } \\
\hline & Coefficient & Standard Error & $t$ & $p$ & LLCI & ULCI \\
\hline Constant & 2.4856 & 0.2345 & 10.6000 & 0.0000 & 2.0243 & 2.9468 \\
\hline DLL & 0.2229 & 0.0617 & 3.6131 & 0.0003 & 0.1016 & 0.3443 \\
\hline \multicolumn{7}{|c|}{ Completely Standardized Indirect Effect of DLL on SI } \\
\hline & Effect & Boot SE & Boot LLCI & Boot ULCI & \multirow{4}{*}{\multicolumn{2}{|c|}{$\mathrm{H}_{4}, \mathrm{~b}:$ Accepted }} \\
\hline ADE & 0.0501 & 0.0168 & 0.0229 & 0.0896 & & \\
\hline \multirow[t]{2}{*}{ Sobel Test } & Effect & Standard Error & z & $\mathbf{p}$ & & \\
\hline & 0.0580 & 0.0198 & 2.9339 & .0033 & & \\
\hline
\end{tabular}

p<0.05, SE: Standard Error, CI: Confidence Interval.

that the highest level of agreement is in the variable of "digital literacy level" ( $\bar{X}=3.73)$. It is seen that the second highest level of agreement is in the variable of "satisfaction with infrastructure" ( $\bar{X}=3.32)$, followed by the variable of "satisfaction with teaching" ( $\bar{X}=2.26)$. It is seen that the dimension with the least agreement level of academicians is "attitude towards distance education" ( $\bar{X}=2.20)$.

According to the analyzes, it has been determined that the digital literacy level positively affects the satisfaction with distance education. The teaching and infrastructure dimensions of satisfaction with distance education are positively affected by the digital literacy level. The results of the studies by Hong (2002), Wei and Chou (2020), and Shih (2006) are similar to the results of this research. Accordingly, it can be said that organizing trainings to increase digital literacy levels for academicians can positively contribute to their satisfaction with distance education during or after the pandemic. In addition, in-service training can be provided to academicians for the use of technology, adaptation to technology and positive change in attitude towards distance education. Thanks to these trainings, both the satisfaction of the academicians with their job and the quality of their courses will increase.

Another result of the study is that the digital literacy level has a positive and significant effect on the attitude towards distance education. This finding is supported by many studies in the literature (Ateş \& Altun, 2008; Brinkerhoff \& Koroghlanian, 2005; Jan, 2018; Tang \& Chaw, 2016). Similar to this finding, it can be said that individual digital literacy is supported by the result that it facilitates the use of distance education and positively affects distance education performance (Mohammadyari \& Singh, 2015). These results show that academicians with high skills in using computers and other communication technologies can approach the distance education process more positively. It is predicted that there is an increase in the digital literacy levels of all academicians due to the use of technology in distance education during the pandemic. This prediction was supported by the study of Ariawan and Pratiwi (2020) on students in the literature. Compulsory distance education experience during the pandemic can positively affect attitudes towards distance education after the pandemic.

The third step result is that the attitude towards distance education has a positive and significant effect on the satisfaction with distance education. Studies in the literature have generally been carried out with students. In these studies, it was revealed that computer competency (Shih, 2006), self-efficacy (Shen et al., 2013), attitude towards distance education (Prior et al., 2016), flexibility in distance education (Alnagar, 2020), quality of distance education and perceived ease of use are factors affecting satisfaction with distance education (Amsal et al., 2021; Sun et al., 2008). All these factors essentially constitute the attitude towards distance education.

The mediating effect of the attitude towards distance education in the relationship between digital literacy level and satisfaction with distance education was tested. According to the 
analysis, it was determined that the attitude towards distance education has a complete mediation role in the effect of digital literacy level on the satisfaction with teaching in distance education. This result reveals the power of academicians' attitudes towards distance education in explaining their satisfaction with distance education. Accordingly, the increase in the level of digital literacy primarily affects the attitude towards distance education positively; Since the attitude towards distance education is positive, satisfaction with distance education increases. Another result reached in the study is that there is a partial mediation effect of the attitude towards distance education in the effect of digital literacy level on infrastructure satisfaction in distance education. Baron and Kenny (1986) state that there is a partial mediation effect as "another variable can mediate between the dependent variable and the independent variable" (Koç, Kaya, Özbek, \& Akkılıç, 2014). Also, while Baron and Kenny (1986) advocate a direct partial mediation effect, those who support the contemporary method argue for the mediation effect by looking at whether there is an indirect effect (Gürbüz, 2019:53; Hayes 2009; Hayes \& Rockwood, 2017). From this point of view, it can be concluded that there may be other variables besides the attitude towards distance education in the relationship between the digital literacy level of academicians and satisfaction with the infrastructure in distance education. Therefore, in order to increase the satisfaction of academicians with distance education, it will not be enough to only strive to increase their digital literacy levels. In addition to the effort to increase the level of digital literacy, the realization of studies that can positively affect the attitudes of academicians towards distance education can increase satisfaction in distance education positively. In addition, it can be said that activities such as increasing the effectiveness of technical support units that may affect infrastructure satisfaction in distance education, holding information meetings for distance education, giving some courses continuously through distance education and strengthening the infrastructure are also very important.

The most important limitation of the study is that it was conducted with academicians in just one university. Another limitation is the possibility of the participants to be affected by pandemic conditions, as the research was conducted during the pandemic. Therefore, conducting the research with different samples after the pandemic will contribute to the literature.

\section{REFERENCES}

Adıgüzel, Z., Çakir, F. S., \& Atalay, A. (2021). The mediation role of perceived organizational support in the effect of workplace spirituality on job control and organizational citizenship. Ataturk University Journal of Economics And Administrative Sciences, 35(1), 125-149.

Afşar, B., \& Büyükdoğan, B. (2020). Assessments of FBAS and FSHS students about distance education during the Covid-19 pandemic period. Journal of Karatay Social Research, (5), 161-182.

Ağaç, S. (2020). Dijital okuryazarlığın finansal okuryazarlık üzerine etkisi: Batı akdeniz örneği (Unpublished master's thesis). Süleymen Demirel Üniversitesi, Isparta.
Akcil, U., \& Bastas, M. (2021). Examination of university students' attitudes towards e-learning during the COVID-19 pandemic process and the relationship of digital citizenship. Contemporary Educational Technology, 13(1), ep291.

Akdemir, Ö. (2011). Distance education in Turkish higher education. Journal of Higher Education and Science, 1(2), 69-71.

Alnagar, D. K. F. (2020). Using artificial neural network to predicted student satisfaction in e-learning. American Journal of Applied Mathematics and Statistics, 8(3), 90-95.

Alshangeeti, A., Alsaghier, H., \& Nguyen, A. (2009). Faculty perceptions of attributes affecting the diffusion of online learning in Saudi Arabia: A quantitative study. Proceedings of the 4th International Conference on E-Learning, 10-24.

Altuntaş, E. Y., Başaran, M., Özeke, B., \& Yılmaz, H. (2020). Perception levels of university students about remote learning strategies and learning experiences in the Covid-19 pandemic process. International Journal of Public Relations and Advertising Studies, 3(2), 8-23.

Amsal, A. A., Lusia, S., Febri, P., Mellyna, R., \& Yan, E. (2021). Perceived satisfaction and perceived usefulness of e-learning : The role of interactive learning and social influence. Proceedings of the 3rd International Conference on Educational Development and Quality Assurance (ICED-QA 2020), 535-541.

Ariawan, V. A. N., \& Pratiwi, I. M. (2020). Digital literacy abilities of students in distance learning. 4th International Conference on Language, Literature, Culture, and Education (ICOLLITE 2020), 592-598. Atlantis Press.

Arklan, Ü., \& Taşdemir, E. (2013). The information society and communication: mass media and internet at the diffusion process of information. Journal of Selcuk Communication, 5 (3), 67-80.

Arslan, S. (2019). ilkokullarda ve ortaokullarda görev yapan öğretmenlerin dijital okuryazarlık düzeylerinin çeşitli değişkenler açısından incelenmesi (Unpublished master's thesis). Sakarya Üniversitesi, Sakarya.

Ateş, A., \& Altun, E. (2008). Investigating preservice computer teachers' attitudes towards distance learning regarding various variables. Gazi University Journal of Gazi Educational Faculty, 28(3), 125-145.

Aylin, Y., Yaylak, E., \& Genç, G. (2020). Digital literacy levels of prospective preschool and primary school teachers. ODU Journal of Social Sciences Research, 10(2), 274-286.

Barış, M. F., \& Çankaya, P. (2016). Opinions of academic staff about distance education. International Journal of Human Sciences, 13(1), 399-413.

Baron, R. M., \& Kenny, D. A. (1986). The moderator-mediator variable distinction in social psychological research: Conceptual, strategic, and statistical considerations. Journal Of Personality and Social Psychology, 51, 1173-1182.

Bayrak Kök, S. (2010). İş tatmini ve örgütsel bağlıı̆ın incelenmesine yönelik bir araştirma. Journal of Economics and Administrative Sciences, 20(1), 291-317.

Biesanz, J. C., Falk, C. F., \& Savalei, V. (2010). Assessing mediational models: Testing and interval estimation for indirect effects. Multivariate Behavioral Research, 45(4), 661-701.

Brinkerhoff, J., \& Koroghlanian, C. M. (2005). Student computer skills and attitudes toward internet-delivered instruction: An assessment of stability over time and place. Journal of Educational Computing Research, 32(1), 27-56. 
Büyüköztürk, Ş. (2018). Sosyal bilimler için veri analizi el kitabı. Ankara: Pegem Akademi.

Can, E. (2020). Coronavirüs (Covid-19) pandemisi ve pedagojik yansımaları: Türkiye'de açık ve uzaktan eğitim uygulamaları. Journal of Open Education Applications and Research, 6(2), 11-53.

Çalık, D., \& Çınar, Ö. P. (2009). Geçmişten günümüze bilgi yaklaşımları bilgi toplumu ve internet. XIV. Türkiye'de internet Konferansı, 12-13.

Çetin, O., Çalışkan, E., \& Menzi, N. (2013). The views of academics about web-based instruction. Elementary Education Online, 12(3), 886-902.

Chen, G. D., Ou, K. L., Liu, C. C., \& Liu, B. J. (2001). Intervention and strategy analysis for web group-learning. Journal of Computer Assisted Learning, 17(1), 58-71.

Churchill, N., Ping, L. C., Oakley, G., \& Churchill, D. (2008). Digital storytelling and digital literacy learning. Proceedings of International Conference On Information Communication Technologies In Education (ICICTE), 418-430.

Çiçekdağı, M., Tekin, E., \& Tekin, M. (2013). Uzaktan eğitim algısı ve imajı: selçuk üniversitesi öğrencileri üzerinde bir uygulama. Ulusal Uzaktan Eğitim ve Teknolojileri Sempozyumu, 81-91. Konya.

Coşkun, R., Altunışık, R., \& Yıldırım, E. (2019). Sosyal bilimlerde araştırma yöntemleri SPSS uygulamalı (10th ed). Sakarya: Sakarya Yayıncılık.

Dalğar, H., Alparslan, A. M., \& Sungur, O. (2017). Factors affecting academic staffs' university satisfaction: comparison between vocational schools and schools/faculties. Mehmet Akif Ersoy University Journal of Social Sciences Institute, 9(21), 412-420.

Durak, G., Çankaya, S., \& Izmirli, S. (2020). Examining the turkish universities' distance education systems during the COVID-19 pandemic. Necatibey Faculty of Education Electronic Journal of Science and Mathematics Education, 14(1), 787-809.

Dursun, T., Oskaybaş, K., \& Gökmen, C. (2013). The quality of service of the distance education. Procedia - Social and Behavioral Sciences, 103, 1133-1151.

Fidalgo, P., Thormann, J., Kulyk, O., \& Lencastre, J. A. (2020). Students' perceptions on distance education: A multinational study. International Journal of Educational Technology in Higher Education, 17, 1-18.

Fidan, M. (2016). Distance education students' attitudes towards distance education and their epistemological beliefs. H. U. Journal of Education, 31(3), 536-550.

Gilster, P. (1997). Digital literacy. New York. John Wiley.

Gök, B., \& Kılıç Çakmak, E. (2020). The Perception of distance education faculty members regarding distance education. Kastamonu Educational Journal, 28(5), 1915-1931.

Gökdaş, I. \& Kayri, M. (2005). E-learning - the problems and solution recommends in terms of turkey situation. Van Yuzuncu Yil University Journal of Education, 2(2).

Gürbüz, S. (2019). Sosyal bilimlerde aracı, düzenleyici ve durumsal etki analizleri. Ankara: Seçkin Yayıncılık.

Gürcan, H. İ. (2011). İnternette medya okuryazarlığı yaklaşımı. XVI. Türkiye'de Internet Konferansı, 30 Kasım-2 Aralık 2011, Ege Üniversitesi Atatürk Kültür Merkezi.
Gürer, M. D., Tekinarslan, E., \& Yavuzalp, N. (2016). Opinions of instructors who give lectures online about distance education. Turkish Online Journal of Qualitative Inquiry, 7(1), 47-78.

Hamutoğlu, N. B., Güngören, Ö. C., Uyanık, G. K., \& Erdoğan, D. G. (2017). Adapting digital literacy scale into Turkish. Ege Journal of Education, 18(1), 408-429.

Harrison, T. (2020). How distance education students perceive the impact of teaching videos on their learning. Open Learning, 35(3), 260-276.

Hayes, A. F. (2009). Beyond Baron and Kenny: Statistical mediation analysis in the new millennium. Communication Monographs, 76(4), 408-420.

Hayes, A. F., \& Rockwood, N. J. (2017). Regression-based statistical mediation and moderation analysis in clinical research: Observations, recommendations, and implementation. Behaviour Research and Therapy, 39-57.

Hayes, A. F., \& Scharkow, M. (2013). The relative trustworthiness of inferential tests of the indirect effect in statistical mediation analysis: Does method really matter?. Psychological Science, 24(10), 1918-1927.

Hebebci, M. T., Bertiz, Y., \& Alan, S. (2020). Investigation of views of students and teachers on distance education practices during the coronavirus (COVID-19) pandemic. International Journal of Technology in Education and Science, 4(4), 267-282.

Hong, K. S. (2002). Relationships between students' and instructional variables with satisfaction and learning from a web-based sourse. Internet and Higher Education, 5(3), 267-281.

llonga, A., Ashipala, D. O., \& Tomas, N. (2020). Challenges experienced by students studying through open and distance learning at a higher education institution in Namibia: Implications for strategic planning. International Journal of Higher Education, 9(4), 116-127.

Inan, C. (2013). Evaluation of the views of faculty members from Dicle University about distance education. Electronic Journal of Education Sciences, 2(4), 66-73.

İstanbul Arel Üniversitesi. (2020). İstanbul Arel Üniversitesi pandemi dönemi uzaktan eğitim sistemi öğretim elemanı memnuniyet anketi. Retrieved from: https://www.arel.edu. $\mathrm{tr} /$ files/website/komisyonlar/akademik_degerlendirme_ve_ kalite_gelistirme_komisyonu/Anket/2020/Pandemi Öğretim Elemanı Memnuniyet Anketi Rapor.pdf.

Jan, S. (2018). Investigating the relationship between students' digital literacy and their attitude towards using ICT. International Journal of Educational Technology, 5(2), 26-34.

Jin, S. H. (2005). Analyzing student-student and student-instructor interaction through multiple communication tools in webbased learning. International Journal of Instructional Media, 32(1), 59-68.

Karabacak, Z. İ., \& Sezgin, A. A. (2019). Digital transformation and digital literacy in Turkey. Türk Idare Dergisi, (488), 319-343.

Karagöz, Y. (2019). SPSS ve AMOS uygulamalı nitel-nicel-karma bilimsel araştirma yöntemleri ve yayın etiği ( 2 nd ed.). Ankara: Nobel Akademik Yayıncılık.

Karatepe, F., Küçükgençay, N., \& Peker, B. (2020). What are the perspectives of teacher candidates on synchronous distance education? A survey study. Journal of Social and Humanities Sciences Research, 7(53), 1262-1274. 
Karavida, V., Charissi, A., \& Tympa, E. (2021). Greek university students' attitudes about distance education due to emergency circumstances. European Journal of Open Education and E-learning Studies, 6(1), 14-24.

Kaya, M., Çitil Akyol, C., Özbek, R., \& Pepeler, E. (2017). Views of academicians in 'department of educational sciences' about 'distance education application' at post-graduate education programs. Electronic Journal of Social Sciences, 16(64), 16161627.

Keleş, M. (2020). Uzaktan eğitim platformlarının avantajları ve dezavantajları. Retrived from: https://binbiriz.com/blog/ uzaktan-egitim-platformlarinin-avantajlari-dezavantajlari.

Keskin, M., \& Özer Kaya, D. (2020). Evaluation of students' feedbacks on web-based distance education in the COVID-19 process. Izmir Katip Çelebi University Faculty of Health Science Journal, 5(2), 59-67.

Koç, F. , Kaya, N. , Özbek, V., \& Akkılıç, M. E. (2014). Mediation effect of perceived service quality between perceived price and consumer trust: A study toward comparison of banking and gsm industries. Journal of Marketing and Marketing Research, 7 (13) , 1-26.

Koloğlu, T. F. (2016). Öğretim elemanlarının uzaktan eğitime bakış açıları ve hazırbulunuşlukları: Ordu üniversitesi örneği (Unpublished master's thesis). Afyon Kocatepe Üniversitesi, Afyon.

Korkmaz, M. (2020). Sınıf öğretmenlerinin dijital okuryazarlık seviyelerinin belirlenmesi (Unpublished master's thesis). Eskişehir Osmangazi Üniversitesi, Eskişehir.

Korucuk, B. (2020). A Study on the rating of distance education satisfaction factors from classroom teachers: An example of Giresun. Instructional Technology and Lifelong Learning, 1(2), 189-202.

Kozan, M. (2018). Bilgisayar ve öğretim teknolojileri eğitimi bölümü öğretmen adaylarının dijital okuryazarlık düzeyleri ve siber zorbalığa ilişkin duyarlılıklarının incelenmesi (Unpublished master's thesis). Fırat Üniversitesi, Elazığ.

Kul, S. (2020). The investigation of the relationship of internet addiction with digital literacy and various other variables. International Journal of Management Information Systems and Computer Science, 4(1), 28-41.

Kurnaz, E., \& Serçemeli, M. (2020). A research on academicans' perspectives on distance education and distance accounting education in the COVID-19 pandemic period. International Journal of Social Sciences Academy, 2(3), 262-288.

Lee, J. A., \& Busch, P. E. (2005). Factors related to instructors' willingness to participate in distance education. Journal of Educational Research, 99(2), 109-115.

Lloyd, S. A., Byrne, M. M., \& Mccoy, T. S. (2012). Faculty-perceived barriers of online education. Journal of Online Learning and Teaching, 8(1), 1-12.

Maphosa, C., \& Bhebhe, S. (2019). Digital literacy: A must for open distance and e-learning (ODeL) students. European Journal of Education Studies, 5(10), 186-199.

Marek, M. W., Chew, C. S., \& Wu, W. V. (2021). Teacher experiences in converting classes to distance learning in the COVID-19 pandemic. International Journal of Distance Education Technologies, 19(1), 40-60.
Markova, T. (2021). Educators' and students' perceptions of online distance education before and amid COVID-19: Key concerns and challenges. In SHS Web of Conferences, 99, 01018.

Mohammadyari, S., \& Singh, H. (2015). Understanding the effect of e-learning on individual performance: The role of digital literacy. Computers and Education, 82, 11-25.

Muilenburg, L. Y., \& Berge, Z. L. (2005). Student barriers to online learning: A factor analytic study. Distance Education, 26(1), 29-48.

Murat, G., \& Çevik, E. İ. (2008). The analysis of factors affecting academic personel satisfaction as stakeholder: The case of Zonguldak Karaelmas University. International Journal of Management Economics and Business, 4(8), 1-18.

Ocak, G., \& Karakuş, G. (2018). Pre-service teachers' digital literacy self-efficacy scale development. Kastamonu Education Journal, 26(5), 1427-1436.

Onursoy, S. (2018). Digital literacy levels of university youth: A research on the students of Anadolu University. Gumushane University e-journal of Faculty of Communication, 6(2), 9891013.

Özdemir, A., \& Gürbüz, A. (2020). Determination of satisfaction levels of the academists: Example of Ağrı Ibrahim Çeçen University. International Journal of Human Studies, 3(5), 163-179.

Özoğlu, C. (2019). Öğretmen adaylarının yaşam boyu öğrenme eğilimleri ile dijital okuryazarlıkları arasındaki ilişki (Unpublished master's thesis). Anadolu Üniversitesi, Eskişehir.

Preacher, K. J., \& Selig, J. P. (2012). Advantages of monte carlo confidence intervals for indirect effects. Communication Methods and Measures, 6(2), 77-98.

Prior, D. D., Mazanov, J., Meacheam, D., Heaslip, G., \& Hanson, J. (2016). Attitude, digital literacy and self efficacy: Flow-on effects for online learning behavior. The Internet and Higher Education, 29, 91-97.

Sari, T., \& Nayir, F. (2020). Challenges in distance education during the (Covid-19) pandemic period. Qualitative Research in Education, 9(3), 328-360.

Sayan, H. (2020). Assessment of faculty members' views on distance education during the

COVID-19 pandemic process. AJIT-e: Online Academic Journal of Information Technology, 11(42), 100-122.

Sekaran, U. (2003). Research methods for business: A skill-building approach, (4th ed). John Wiley \& Sons.

Shrout P.E., \& Bolger N. (2002). Mediation in experimental and nonexperimental studies: New procedures and reccomendations. Psychological Methods, 7, 422-445.

Stone, C. A., \& Sobel, M. E. (1990). The robustness of estimates of total indirect effects in covariance structure models estimated by maximum. Psychometrika, 55(2), 337-352.

Sobel, M. E. (1982). Asymptotic confidence intervals for indirect effects in structural equation models. Sociological Methodology, 13, 290-312.

Shen, D., Cho, M.-H., Tsai, C.-L., \& Marra, R. (2013). Unpacking online learning experiences: Online learning self-efficacy and learning satisfaction. The Internet and Higher Education, 19, 10-17. 
Shih, Hung-Pin, (2006), Assessing the effects of self-efficacy and competence on individual satisfaction with computer use: An it student perspective. Computers in Human Behavior, 22(6), 1012-1026.

Sun, P. C., Tsai, R. J., Finger, G., Chen, Y. Y., \& Yeh, D. (2008). What drives a successful e-learning? An empirical investigation of the critical factors influencing learner satisfaction. Computers and Education, 50(4), 1183-1202.

Tabachnick, B. G., \& Fidell, L. S. (2013). Using multivariate statistics (6th. ed). Boston: Pearson Education.

Tang, C. M., \& Chaw, L.Y. (2016). Digital literacy: A prerequisite for effective learning in a blended learning environment?. The Electronic Journal of e-Learning, 14(1), 54-65.

Thach, E. C., \& Murphy, K. L. (1995). Competencies for distance education professionals. Educational Technology Research and Development, 43(1), 57-79.

Tuncer, M., \& Tanaş, R. (2011). The evaluation of academicians' views on distance education programs (The samples of Firat and Tunceli Universities). Elementary Education Online, 10(2), 776-784.

TUIK.(2020). Hanehalkı bilişim teknolojileri (BT) kullanım araştırması. Retrieved from: https://data.tuik.gov.tr/Bulten/ Index? $\mathrm{p}=$ Hanehalki-Bilisim-Teknolojileri-(BT)-KullanimArastirmasi-2020-33679.

Üstündağ, M. T., Güneş, E., \& Bahçivan, E. (2017). Turkish adaptation of digital literacy scale and investigating preservice science teachers' digital literacy. Journal of Education and Future, (12), 19-29.

Uzun, Y., \& Çelik, G. (2020). Changes in academicians' perception of literacy. International Journal of Society Researches, 15(22), 1134-1156.
Wang, L., \& Preacher, K. J. (2015). Moderated mediation analysis using Bayesian methods. Structural Equation Modeling: A Multidisciplinary Journal, 22(2), 249-263.

Wei, H.-C., \& Chou, C. (2020). Online learning performance and satisfaction: Do perceptions and readiness matter?. Distance Education, 41(1), 48-69.

World Health Organization. (2019). Coronavirus disease (COVID-19) pandemic. Retrieved from: https://www.who.int/ emergencies/diseases/novel-coronavirus-2019.

Wilson, D., Varnhagen, S., Krupa, E., Kasprzak, S., Hunting, V., \& Taylor, A. (2003). Instructors' adaptation to online graduate education in health promotion: A qualitative study. Journal of Distance Education, 18(2), 1-15.

Yağcı, K., Efendi, M., \& Akçay, S. (2019). Concept of distance education: From perspective of tourism guidance students. Journal of Travel and Tourism Research, (14), 118-136.

Yener, S. (2017). THE mediating role of psychological safety in the relation between employee voice and team collaboration. Dokuz Eylul University The Journal of Graduate School of Social Sciences, 19(2), 187-204.

Yeşildal, M. (2018). Yetişkin bireylerde dijital okuryazarlık ve sağlık okuryazarlığı arasındaki ilişki: Konya örneği (Unpublished master's thesis). Necbettin Erbakan Üniversitesi, Konya.

Zan, N., \& Zan, U. B. (2020). Education in emergency at coronavirus: Overview of faculty of letters students included to distance education system from different regions of turkey. Turkish Studies, 15(4), 1367-1394.

Zhao, X., Lynch, J. G., \& Chen, Q. (2010). Reconsidering Baron and Kenny: Myths and truths about mediation analysis. Journal of Consumer Research, 37(3), 197-206. 